\title{
Civil Society Organizations and Post-Conflict Reintegration in Niger Delta, Nigeria
}

\author{
Juliana Popoola \\ University of Ibadan, Ibadan, Nigeria \\ Email:gbemileke52@gmail.com
}

How to cite this paper: Popoola, J. (2020). Civil Society Organizations and Post-Conflict Reintegration in Niger Delta, Nigeria. Open Journal of Political Science, 10, 668-696. https://doi.org/10.4236/ojps.2020.104039

Received: July 28, 2020

Accepted: October 11, 2020

Published: October 14, 2020

Copyright $\odot 2020$ by author(s) and Scientific Research Publishing Inc. This work is licensed under the Creative Commons Attribution International License (CC BY 4.0).

http://creativecommons.org/licenses/by/4.0/

\begin{abstract}
Post-conflict reintegration is an aspect of peacebuilding that deals with the social, political and economic integration of ex-combatants and their families. It is a long-term process that provides a primary support network into civil society (Nilson, 2005). The research aimed to examine the role(s) of civil society organizations in post-conflict Reintegration of Niger Delta, Nigeria. Civil society is the "third sector" of society. The research adopted the descriptive-evaluative research design and used a secondary source for data collection. The research findings show that the struggle for resource control between the Nigerian government and indigenes of the Niger Delta is the root source of the conflict. The 2009 Presidential Amnesty Programme (PAP) was implemented to reconcile these differences and promote stability in the region and country at large. The success of the amnesty programme was hindered by lots of challenges encountered both from the national government and the ex-combatants. Nonetheless, with the support of civil society organizations, PAP recorded several successes.
\end{abstract}

\section{Keywords}

Include Post-Conflict Reintegration, Peacebuilding, Civil Society

Organizations, Ex-Combatants

\section{Introduction}

The Niger Delta is an oil-rich region in Nigeria. Historically and geologically, it consists of present-day Bayelsa, Delta and Rivers state. However, former President Olusegun Obasanjo added the remaining six oil-producing states in the region. Table 1 shows the geographical data of Niger Delta, Nigeria, while Figure 
1 shows the map of the Niger Delta region. The Niger Delta is rich in diverse resources, particularly, petroleum. The discovery of oil in the Eastern region of Nigeria in 1958 marked a turning point in the nation's economy. The country shifted from agriculture to crude oil as the primary source of revenue and foreign exchange (Usman, 2008). About eighty per cent of the oil in Nigeria is explored from the Niger Delta region.

Table 1. Geographical data of Niger Delta, Nigeria.

\begin{tabular}{|c|c|}
\hline Factors & Data \\
\hline Region & $\begin{array}{c}\text { Delta of the Niger River directly on the Gulf of Guinea } \\
\text { on the Atlantic Ocean in Nigeria }\end{array}$ \\
\hline Space Area $\left(\mathrm{km}^{2}\right)$ & 70,000 \\
\hline Population & 31 million people Technical Committee on the Niger Delta (2008: p. 102) \\
\hline States & $\begin{array}{c}\text { Bayelsa, Delta, Rivers, Ondo, Akwa-Ibom, Edo, } \\
\text { Cross River, Abia and Imo states }\end{array}$ \\
\hline Ethnic Groups & Over 40, including Ogoni, Ibibio, Okrika, Ikwerre, Kalabari. \\
\hline Languages & Ijaw, Itsekiri, Central Delta, Edoid and Igboid \\
\hline Revenue Source & Crude Oil and gas deposits \\
\hline Major groups & $\begin{array}{c}\text { Niger Delta People Volunteer Force (NDVF), } \\
\text { Niger Delta Vigilante (NDV), } \\
\text { Ijaw Youth Council (IJC), MOSOP }\end{array}$ \\
\hline
\end{tabular}

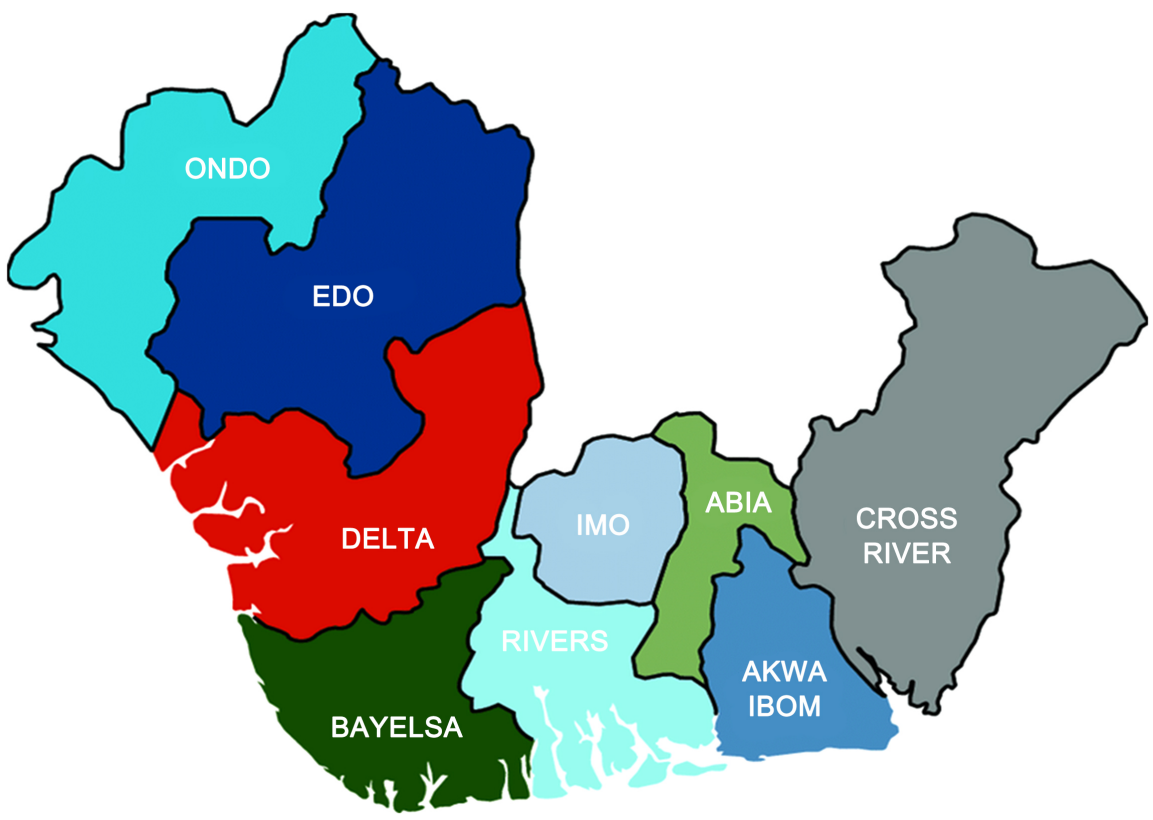

Figure 1. Map location of Niger Delta, Nigeria. List of states that makes up the Niger Delta region (Nigerian Infopedia). 
The Niger Delta conflict can be traced back to the 1990s but became renowned during the Nigerian civil war. The effect of the conflict led to civil and political unrest in the region and the whole of Nigeria. Various militant groups emerged and were involved in hostage-taking, illegal oil bunkering, pipeline vandalization, the kidnapping of expatriates and piracy hijacking (Osah \& Alao, 2014; Aaron \& George, 2010; Watt, 2010). Several factors contributed to the Niger Delta agitation: the struggle for resource control, environmental degradation of the region, economic underdevelopment, high unemployment, repressive response of the federal government to the cries of the indigenes, the 1978 Land Use Decree, the death of Agbarator Otu and Ken Saro-Wiwa, and the rivalry between the various armed groups. In the bid to restore order in the country, the 1957 Willink Commission; 1961 Niger Delta Development Board; 1978 Land Use Decree; 1990 Ogoni Bill of Rights; 2000 Niger Delta Development Commission; 2004 Niger Delta Regional Development Master Plan; 2006 UNDP HDR; and the 2008 Presidential Technical Committee on the Niger Delta were introduced at various phases of the conflict (HRW, 1999; Obi, 2009; Ebeku, 2001; Elowyn, 2011; Technical Committee on the Niger Delta, 2008). With the understanding of the nature of conflict in Niger Delta, this research aims at discovering the principal peacebuilding actor(s) in Niger Delta area, examining the roles of civil society organizations in the post-conflict reintegration of the Niger Delta, and explores the challenges posed in Niger Delta peacebuilding. The study adopts the descriptive and evaluative research design to analyze past data and arrive at a valid conclusion. A secondary source was also used for data collection through journals, articles, newspapers, government publications, e-library resources, reports and publications.

\section{Literature Review and Definition of Terms}

The concepts to be clarified in this section are civil society organizations, peacebuilding and post-conflict reintegration.

\subsection{Civil Society Organizations (CSOs)}

Like every other concept in the social sciences, civil society does not have a single definition. However, various scholars have attempted to construe meaning to it based on their observations on the roles played by various actors. Some scholars define it based on its power outside the realms of the state; some describe it based on its restriction to associational life while others define civil society as voluntary organizations that are neither the state nor family.

Based on a power outside the realm of the state, Fukuyama (1995) defines civil society as the field of impulsively created social systems distinct from a state that inspires democratic political institutions. Its relationship domain falls between the family and the state; private spheres and public domains (Dunn, 1996). Civil society is a social environment that portrays and anticipates a diverse and competitive group of NGOs that are nonviolent, self-reflecting, self-organizing and 
tensed continuously with each other and institutions of government that allow them to work together.

Addressing civil society based on its restriction to associational life, Kligman (1990) defines it as a network of autonomous, state-independent associations linking people together in areas of common interest and through their nature and actions, may influence public policy. Schmitter (1995) sees it as a set of self-organized transitional groups.

As a voluntary organization, scholars like Tester (1992) defined civil society as social relations involving the voluntary association and contribution of individuals in a private capacity. In a simplified way, it can be equated to a dynamic personal relationship. It is cumulative of organizations whose members are engaged in compound non-state activities (Makumbe, 1998). It is the aggregate of institutions situated and interconnected between the family and community, and on the other hand, the government and state (Keane, 1988: p. 20; Bratton, 1992: p. 56; Harbeson et al., 1992: pp. 285-290; Ikelegbe, 1999).

CIVICUS (2011) is the most widely accepted definition of civil society. It defines civil society as the environment created by an individual and collective actions and organizations to foster common interest beyond the affairs of the family and state. Civil society has different actors. They are:

- Civil society organizations: it is made up of NGOs, faith-based and community-based groups having an organized structure, mission and are legally registered.

- Online activities: it comprises organized social media communities that do not necessarily have legal or financial structures.

- Labour organizations: this union represents workers.

- Social movements: it involves online or physical collective action and identity.

- Social entrepreneurs: it employs market-oriented approaches for social and environmental outcomes.

Civil society, as a voluntary organization, will be adopted for this research. Civil society organizations (CSOs) has been conceived more broadly by African scholars to include every organized social life of communities, groups and individuals related to their necessities, needs, existence and survival (Ikelegbe, 2013). $\mathrm{CSO}$ is the aggregate of non-governmental organizations that manifest interests and resolve of citizens and are sometimes referred to the third sector of the society, distinct from government and business.

\subsection{Peacebuilding}

Peacebuilding refers to the activities and actions of state and non-state actors at all levels to address the source of conflict and ensure that civilians are free from fear and actions that are life-threatening. It is a process that promotes long-lasting peace through institution building, settlement, political and economic renovation, and seeks to prevent the violence from recurring by addressing the source of the conflict. The Brahimi Report (2000) defines peacebuilding 
as the set of activities in a post-conflict state aimed at reassembling the basis of peace and providing the conditions for its reconstructing, rather than the mere absence of war. The UN Secretary-General Boutros Boutros-Ghali (1992) describes peacebuilding as an act of post-conflict recognition and support for peace processes aimed at preventing conflict relapses. It is a process designed to address inequality peacefully and to change cultural and systemic structures, including violence prevention and conflict resolution that leads to death or destruction.

\subsection{Post-Conflict Reintegration}

Post-conflict denotes a reduction in hostilities. It is the window of opportunity for peace in a conflict which can escalate again if maladministered (Fischer, 2004: pp. 2-3; Hamre and Sullivan, 2002: p. 90). Reintegration, on the other hand, is the social, political and economic incorporation of soldiers, their families and their first network of support into civil society (Nilson, 2005). It is an open time frame process designed to foster the acclimatization of ex-combatants into civilian status. Reintegration is not one general process; instead, it consists of a series of micro-stories, individual and group efforts with successes and setbacks (Kingma, 2001).

Post-conflict reintegration, therefore, is a social and economic process that facilitates the transition and adaptation of ex-combatants into civilian status after a just-concluded war or violence.

\subsection{Literature Review}

Peacebuilding originated in the field of peace studies more than thirty years ago. It was coined by Johan Galtung (1976), in his pioneering work "Three Approaches to Peace: Peacekeeping, Peacemaking, and Peacebuilding”. He posits that peace has a structure different from peacekeeping and peacemaking. Peacebuilding is a multidisciplinary, cross-sector technique or method which becomes strategic when it works over the long run and at all levels of the society to establish and sustain relationships among people both locally and globally, thus, fostering sustainable peace (Anderson, 2015). It addresses the root cause of conflict and seeks to achieve long-term peace. Joan B Kroac Institute for Peace and Justice, University of San Diego has identified some basic principles for peacebuilding. Peacebuilding is multifaceted and has many actors; it entails values, mandates, civil rights and needs; it extends beyond conflict transformation; it relies on social skills; it reconciles differences and transforms relationships; it addresses inequality and violence; it is based on the idea of interdependence, collaboration and minimal conflict; it addresses root causes of conflict and underlying cultures; it creates an environment for interpersonal relationships; and it requires capacity and relationship building at multiple levels.

The international system is anarchical. States engage in conflict with each other either on land, airspace, water or underwater. Thus, peacebuilding is a vital 
process in maintaining peace and security. The notion of peacebuilding refers to "rebuilding the institutions and infrastructures of nations torn by civil war and strife; and building bonds of peaceful mutual benefit among nations formerly at war; and in the largest sense, to address the deepest causes of conflict"

(http://www.peacebuildinginitiative.org/). The concept was extended in 1995, to address phases of the conflict in "Supplement to An Agenda for Peace", which stressed more importance on establishing structures for the institutionalization of peace. Meanwhile, “An Agenda for Development” (United Nations, 1994) serial publications, “An Agenda for Democratization” Boutros-Ghali (1996) and the UNDP (1994) Report on Human Security have contributed significantly to the interaction between issues under the security plan and matters related to development, democracy and human rights.

Peacebuilding is a form of human security which cater for the protection and security of individuals. It is widely used to describe the sophisticated, consistent threats associated with violence and war. Similarly, peacebuilding tends to investigate the root cause of conflict to proffer ways by which peace can be sustained. The concept of peacebuilding became widespread after the publication of the 1992 Agenda for Peace by the then UN Secretary-General Boutros Boutros-Ghali. The UN plays a significant role in peacebuilding processes through peacekeeping and DDR programmes.

Peacebuilding connotes four things: disarmament, demobilization, reconstruction and reintegration (DDRR). Disarmament refers to the removal of military forces and weapons in a warzone. It is the surrendering of arms by combatants in a bid of restoring peace in a community. Demobilization is the process of dissolving armed groups from a combat-ready status following war victory or conflict resolution. Reconstruction is the process of recreating demolished or damaged structures during violence or war. Reintegration, on the other hand, is the process of restoring and unifying ex-combatants or demobilized forces back into civilian society to ensure sustainable peace.

\subsection{The UN and Peacebuilding}

The United Nations is the foremost intergovernmental organization charged with the responsibility of maintaining international peace and security. In achieving this goal, the UN engages in several peacebuilding and peacekeeping operations. The UN works with the support of other international and non-governmental organizations. The mandates of multi-dimensional peacekeeping operations include many peacebuilding tasks. These are: disarmament, demobilization and reintegration (DDR), security sector reform (SSR), support to electoral processes and re-establishing governmental authority (UNSCR) of which international and national civilian staff are employed to support those tasks. The UNDP Bureau for Crisis Prevention and Recovery has developed some capacity to deal with post-conflict issues such as mine removal, disarmament, and small arms-recovery. At the same time, UNHCR works on protecting and resettling 
refugees and internally displaced persons during and after conflict.

According to the 1992 UN document, An Agenda for Peace, peacebuilding can be understood in two ways:

1) as a comprehensive process that involves peacemaking, peacekeeping and post-conflict development (Pre-conflict);

2) as a wide range of activities associated with capacity building, reconciliation, and societal transformation-that is, the phase that comes after peace has been restored in a community (Post-conflict).

Peacebuilding includes early warning and response efforts towards conflict, violence prevention, advocacy work, civilian and military peacekeeping, military intervention, humanitarian assistance, ceasefire agreements, and the establishment of peace zones. Although peacebuilding includes pre-conflict responses which many scholars advocate for an increased focus on; in practice, most peacebuilding interventions are post-conflict. Rotberg (1996) asserts that continuous preventive action, or what the UN now refers to as post-conflict peacebuilding seeks to prevent conflicts from recurring where they have already taken place.

Most times, the UN initially gets involved when the conflict poses a threat to international peace and security or if the country calls for international assistance. The first 24 months in a post-conflict region is crucial and strategic as there can be a relapse of violence. The UN responds more quickly and effectively in peacebuilding once a negotiated settlement has been reached and there is an element of peace. During the early days of the post-conflict era, the UN, alongside other international actors provides various resources and assistance to help the people get accustomed back to a peaceful reign while national capacity is being developed to ensure the furtherance of peace and stability. According to a report of the UN Secretary-General on peacebuilding, Kofi Annan, the primary objectives to be achieved during this period include:

1) Build stability in the areas affected, including civil defense, disarmament, demobilization and reintegration and implement security sector reform.

2) Strengthen faith in the democratic process by improving the rule of law, restoring interest in election proceedings, expanding national and sub-national dispute resolution capability.

3) Promote basic infrastructures, such as food, sanitation, power, health and primary education, secure and permanent returns and resettlement of internally displaced people and refugees.

4) Restore core functions of the government at the state and regional level, particularly basic public administration and public finance.

5) Economic revitalization, particularly for young people and demobilized retired troops (in agriculture and public works) and restored basic services.

Barnett et al. (2007) also categorize post-conflict peacebuilding into three: stabilizing the post-conflict zone (reinforcing state stability and deterring former combatants from returning to war via disarmament, demobilization and reinte- 
gration), restoring state institutions (through building state capacity to provide basic public goods and increase state legitimacy), and dealing with social and economic issues (by building a post-conflict society's ability to manage conflicts peacefully and promote socio-economic development). The new approach which the UN refers to as "Second Generation DDR Practices" has to cope with post-civil conflict societies and environments where "warlordism", ethnic and religious disturbances, gangs, militias and irregularly armed elements abound at the sub-national level (UN DPKO, 2010).

\section{Theoretical Framework}

Conflict Transformation theory will be used to describe and support this study. Miall (2004) notes that the conflict transformation theory is seen as a re-conceptualization of peacebuilding to make it more relevant to contemporary conflict situations. Conflict transformation encompasses conflict management (Bloomfield \& Reilly, 1998) and conflict resolution (Deutsch \& Coleman, 2000).

Conflict management is a method of managing and avoiding confrontation that can disrupt the smooth functioning of society. It is the constructive handling of differences and divergence. Conflict management aims at attaining diplomatic agreements by allocating the resources of specific leading players who have the necessary power to steer and resolve the future dispute through appropriate networks (Bloomfield \& Reilly, 1998).

On the other hand, conflict resolution concentrates on intervention by professional and non-powerful third actors engaging outside the political system by allowing the actors to consider, discuss, evaluate, challenge, reframe and articulate positions and desires. Conflict resolution involves helping conflicting parties to transition from zero-sum engagements to positive-sum outcomes (Deutsch \& Coleman, 2000).

Summing both together, conflict transformation, according to Lederach (2003) forecasts and reacts to the upsurge and movement of social tensions as ways to create successful transition processes. It is the ability to refrain from positions, identify positive outcomes, create a new framework and strategy that consolidates and strengthens the benefits of resolving conflict and establishing peace. It is a long-term process involving the efforts of various actors. These actors are grouped into four different aspects.

1) States and Inter-governmental organizations: The state is the most important actor in peacebuilding effort as the impacts of their practices most directly and powerfully affects conflicting parties. State actions have positive or negative consequences in the public domain. The inter-governmental organization, here, is the United Nations who has been involved with several peacebuilding activities and efforts to ensure and sustain peace in different parts of the world which in turn will maintain international peace and security. These actors are essential in any peacebuilding effort as they determine the progress of the programme or not based on the actions to which they undertake in a situation. 
Many states seek the assistance of the UN in its peacekeeping and peacebuilding operations as they by themselves, do not have enough power to achieve it themselves. No peace operation can be carried out in isolation by the government of a state itself. It requires the support of other non-state actors, either inter-governmental organizations or non-governmental organizations, to achieve sustainable peace.

2) NGOs focusing on conflict prevention and transformation: they seek comprehensive knowledge of conflict origins, work together with the local people, both inside and beyond parties in conflict. These actors are directly closer to the people and perform various activities and roles towards ensuring effective peacebuilding in a country. They help in supporting and sustaining domestic and social groups, build peace in communities, strengthen capability, empower principal actors, engage in organizational development, network and training.

3) Development and Humanitarian Organizations: these actors are involved in reconstructing post-conflict states and respond to severe damage to national growth which results from armed conflict. In some cases, their activities support UN peacebuilding operations. For instance, Mozambique where donors helped to keep the elections on schedule and supported the transformation of RENAMO into a political party. The essence of this actor is to provide development aid and humanitarian assistance to victims of war. Sometimes, their development aid can be directed to alleviate conflict to reduce conflict or discontent in a politically unstable area. They also engage in activities to support the reintegration of child soldiers or the rehabilitation of ex-combatants or agitators which have and is a peacebuilding component. The presence of development aid can either sustain conflict (Nigeria civil war where assistance was given to the people of Biafra which supported the fight for 30 months) or put an end to the conflict in a war-torn country.

4) Parties to the conflict and other relevant groups within the affected societies: they have an enormous responsibility in conflict transformation. They are the ones involved in the battle and have the means to end or elongate the conflict. They are also crucial in conflict transformation as the reconciliation is between the conflicting parties.

The theory of conflict transformation explains the long-term process of transforming from conflict to peace which involves the efforts of various actors in trying to achieve a successful peacebuilding operation. The government cannot by itself engage in peacebuilding effort; it needs and requires the assistance of other actors to effectively transform from conflict to peace and sustain it for the long term.

\section{The Roles of CSOs in the Post-Conflict Reintegration in Niger Delta, Nigeria}

The Niger Delta region was faced with militancy struggle and violent conflicts 
which had caused the country to lose millions of dollars due to the inability of the oil companies in the region to produce as they feared for their lives and security. The insecurity in the region cost the companies millions of naira, equipment was destroyed and their staff, attacked. Thus, the Federal Government in Nigeria under the administration of late President Umaru Musa Yar'Adua introduced the Presidential Amnesty Program (PAP) on 11 Jul. 2009. It was a step towards addressing the adverse security situation in the region and implemented for sixty days.

The Presidential Amnesty Program is a form of peacebuilding strategy used by the Nigerian government to restore peace and foster economic development in the country. PAP was implemented in three stages: disarmament, demobilization and reintegration. At the disarmament phase, militants were asked to surrender their weapons and ammunition between August to October 2009 in exchange for their crimes being pardoned (Oluwaniyi, 2011a). The demobilization phase took the nonviolent transformation of the ex-combatants to civilian status. The reintegration stage involved the training, educating and engaging the ex-combatants in activities to foster the smooth transitioning and living of the civilian life.

\subsection{Peacebuilding in Niger Delta}

The peacebuilding programme in Niger Delta was organized by the Nigerian government and took the support of various civil society actors. The Nigerian government adopted some strategies in implementing the peacebuilding programme to achieve sustainable peace. The Niger Delta Technical Committee (NDTC) was formed in 2008 by the late President Umar Musa Yar'Adua to recommend strategies for conflict resolution in the region (International Crisis Group, 2006). Amongst the recommendations made was the amnesty program through DDR programs. The PAP was implemented between August to October 2009.

The disarmament phase took place in designated centres like Edo state, Cross River, Delta, Akwa Ibom, Rivers and Bayelsa states (Watt, 2010). The Nigerian Army majorly conducted it. It was discovered during this phase that over 2500 sophisticated guns and 300,000 ammunitions were laid down by 15,000 ex-agitators (Udegbuman, 2013). Manyammunitions were also recovered from the various Niger Delta states (Uzodinma, 2013).

The government thereafter set-up campgrounds as centres for the demobilization phase. This phase aimed to resettle the ex-militants into productive labour. The end of military conflicts gives displaced populations and nations the possibility of restoration and regeneration of their communities, economies and politics. This phase took the form of biometrics, identification, verification and documentation of ex-combatants who were in the designated camp centres. Oluwaniyi (2011b) notes that the demobilization process was accompanied by an offer from the government to pay the ex-combatant's monthly stipends of sixty-five thousand naira. This was to cater for their food and cash allowances and 
dissuade them from engaging in criminal activities until the end of the amnesty programme.

The rehabilitation and reintegration phase were the final stages of the amnesty program. The rehabilitation allowed for the ex-combatants to be reoriented and prepared towards the training and educational skills of the reintegration programme (Ibude, 2011). Ikelegbe (2010) notes that the ex-militants were initially camped at Aluu, Rivers state before being moved to Obruba. He posits that the Aluu camp could accommodate only 800 out of 7000 ex-combatants. During the reintegration phase, the former agitators were empowered socially, economically, culturally and politically. It involved vocational and entrepreneurial training, technical skills, development, formal and informal education and the opportunity to be granted paid employment. This phase was in two steps: conflict management training and counselling (Udegbuman, 2013).

\subsection{Post-Conflict Reintegration in Niger Delta, Nigeria}

The United Nations (2006) defines reintegration as "the process by which former militants attain civilian status and gain sustainable employment and income". The Nigerian government was the major actor in the reintegration of the Niger Delta ex-militants. Local and international peace actors supported it.

In the Niger Delta, both the ex-combatants and non-combatants were beneficiaries of the reintegration programme. According to the International Crisis Group, the Nigerian government implemented the reintegration in two phases. First was the structural discussion they had with the leadership of the ex-combatant's group, imploring them to create private firms that would be contracted to secure the oil pipelines and other installations since they knew the vicinity and security challenges of the region. It was believed that this would prevent them from going back to their past life of carrying arms as they will have a legal source of income that makes them live large as they did during the war. The second phase was the inclusion of non-combatants in the reintegration process, as they were also victims of war (UN, 2010). There were various skill acquisitions, educational and vocational training offered in the programme. Some people were also sent abroad, some to other African countries and others got reintegrated in Nigeria. They were all fully funded by the Nigerian government, some oil companies and some international organizations (Folami, 2014).

The oil companies formed the Oil and Gas International Foundation (OGIF) to support the reintegration process. OGIF trained about 3000 ex-combatants (Abazie-Humphrey, 2014). A document from the amnesty office indicates that the programme covered up to 157 universities and 22 vocational training centres in countries all over the world. The Office of the Special Adviser to the President on Niger Delta (OSAPND, 2014) reports that the local education and vocational training programmes involve nine universities and nineteen professional training centres in eight states in Nigeria.

The training during the reintegration programme was of high quality com- 
pared to the reintegration programme of other African countries (OSAPND, 2014). Alusala (2011: p. 66) says the lack of adequate training during the reintegration programme is one of the challenges facing Liberia as there is the probability of violence recurrence. The education and training received enabled them to integrate properly into civilian life and to have hope for future endeavours having studied in such renowned universities. He further went on to say that the vocational training employed for the ex-combatants were of high value and prospects to their future and the country at large. Table 2 shows the data for the reintegration programme of the Niger Delta.

The Office of the Special Adviser to the President of the Niger Delta stated that employment opportunities were provided for beneficiaries who have trained abroad through the partnership of the Nigerian government, the government of the foreign schools and some private bodies. For instance, about fifty of those that went for welding and fabrication training at Proclad Group in Dubai were automatically offered employment by the institution upon completion of their training; some got employed immediately after their training in their different fields in shipping companies (OSAPND, 2014). OSAPND stated that alongside those who had their training in Dubai, forty-nine trainees, who underwent training at Scuola Edile Genovese in Italy also gained employment at different shipping companies, locally and internationally after their training. Fourteen

Table 2. Data for Niger Delta reintegration programme.

\begin{tabular}{|c|c|}
\hline Factors & Data \\
\hline Actors & $\begin{array}{c}\text { The Nigerian government, international } \\
\text { organizations and local NGOs }\end{array}$ \\
\hline Beneficiaries & Ex-combatants and non-combatants \\
\hline Training centres & 157 universities, 22 vocational training centres \\
\hline Reintegration centres & $\begin{array}{l}\text { Home and abroad-other African countries, } \\
\text { western countries }\end{array}$ \\
\hline Skills & $\begin{array}{l}\text { Formal and informal education, pilot training, drilling engineering, } \\
\text { technicians for petroleum and mining industry, furniture making, } \\
\text { welding and fabrication and many more }\end{array}$ \\
\hline $\begin{array}{l}\text { Abroad Educational } \\
\text { centres }\end{array}$ & $\begin{array}{l}\text { Salford University, Bradford University, Coventry University, } \\
\text { Portsmouth University, etc. (OSAPND, 2014) }\end{array}$ \\
\hline $\begin{array}{l}\text { Vocational training } \\
\text { centres abroad }\end{array}$ & $\begin{array}{l}\text { Lufthansa Aviation Academy (Germany), CAE Oxford Aviation } \\
\text { Academy (United Kingdom), Institute of French Petroleum (France), } \\
\text { Schlumberger Technologies (France), Adcorp Technical Training } \\
\text { (South Africa), Institute of French Petroleum (France), } \\
\text { Furntech Furniture (South Africa), Proclad Group (Dubai), } \\
\text { ScuolaEdile Genovese (Italy) and many more }\end{array}$ \\
\hline
\end{tabular}

Source: OSAPND, 2014. 
trainees who trained as mechatronics and welding engineers got employed at Samsung Electronics, and Schneider Electric in France used fifteen trainees in power management after their training at the company (Daniel, 2014).

Also, he stated that the government, in conjunction with some non-governmental organizations were making considerable effort to provide funds for those willing to set-up small scale businesses for at least four thousand beneficiaries of the reintegration programme. As of 2014, over two-thousand ex-combatants gained employment and have set-up their firms (Vanguard News, 2014). As at 2014, 2204 trainees had graduated from small scale business, 2798 from oil drilling while 916 from marine engineering courses and programme. Also, 299 trainees were engaged in building boats, 1030 were engaged with cranes and heavy-duty, while 239 were into agriculture (Ikelegbe \& Umukoro, 2014). Following the progress of the integration programme, despite calls for the end and closure of the programme and vocational training, many still clamour for its sustenance and thus, the President, Muhammadu Buhari declared a two-year extension while describing this present phase as an exit strategy (Olokor, 2016).

\subsection{CSOs That Contributed in the Peace Process of Niger Delta Struggle}

The CSOs have been active in peacebuilding activities in the state through reducing conflict, violence, work with communities, town hall meetings, and include the opinion of women, youth and adult to prevent and contain local conflict and build peace initiatives. The CSOs are there to act as the intermediary between the public and the government, provide services and opportunities that will help improve the living standard of the individual and the community at large. They played an enormous role in training and education projects for community people, facilitating service delivery, advocating for peaceful strategies, monitoring and reducing conflicts, fighting against violations of rights and peace efforts, assisting in re-socialization and orientation processes and facilitating dialogue and intergroup social cohesion (Paffenholz, 2009).

Civil Society Organizations played a considerable role in the reintegration programme in Niger Delta, Nigeria. Civil society has been articulated as having tremendous implications for shaping and pluralizing power relations (Keane 1988: p. 13), broadening the avenues of societal representation of interests and individual and group influence and participation (Harbeson et al., 1992), creating a new political culture of citizenship that stresses rights, obligations, protest and contestation (Grindle, 1996: p. 7), and promoting political liberalization (Keane, 1988: p. 12). It has been established that the peacebuilding process in Niger Delta was a combined effort of both the Nigerian government (primary actor) and civil society organizations, both locally and internationally. Ikelegbe (2001) divided the local CSOs into four: Ethnic youth associations; Pan-ethnic civil society; environmental and civil human rights group; and the communal and ethnic civil society. Tables 3-6 show the different civil society groups and their objectives. 
Table 3. Outline of ethnic youth associations in Niger delta.

\begin{tabular}{|c|c|c|c|c|c|}
\hline $\mathrm{S} / \mathrm{N}$ & Civil society & Objectives/Grievances & Actions & Leaders & Period \\
\hline 1 & $\begin{array}{l}\text { Ijaw Youth Council } \\
\text { (IYC) }\end{array}$ & $\begin{array}{l}\text { Criticizes marginalization, } \\
\text { ignores suppression } \\
\text { Demands compensation, } \\
\text { development, resource control } \\
\text { \& federal restructuring }\end{array}$ & $\begin{array}{l}\text { Made Kaiama Declaration; } \\
\text { Extended violence with state } \\
\text { security; Demandsoil companies } \\
\text { to leave Ijawland, Confiscated } \\
\text { oil facilities. Press releases }\end{array}$ & $\begin{array}{l}\text { Collective leadership } \\
\text { led by Isaac Osuaka }\end{array}$ & $\begin{array}{c}\text { Ijaw } \\
1999-2000\end{array}$ \\
\hline 2 & $\begin{array}{c}\text { Ikwere Youth } \\
\text { Movement (IYM) }\end{array}$ & $\begin{array}{l}\text { Community and employment } \\
\text { benefits from WILBROS } \\
\text { oil company }\end{array}$ & $\begin{array}{l}\text { Criticized the appointment of } \\
\text { OMPADEC chairman through press } \\
\text { (1998). Occupied WILBROS in } \\
\text { Chobaprotest at PH (October 1999) }\end{array}$ & Uche Okechukwu & $\begin{array}{c}\text { Ikwerre } \\
1998-2000\end{array}$ \\
\hline 3 & $\begin{array}{l}\text { Isoko National Youth } \\
\text { Movement (INYM) }\end{array}$ & $\begin{array}{l}\text { Complaints of neglect, and } \\
\text { degradation. Demand for equity } \\
\text { and development. }\end{array}$ & $\begin{array}{l}\text { Shut down of } 5 \text { oil flow stations } \\
\text { in Isokoland in 1998-1999; } \\
\text { Media reports; meeting with govt. } \\
\text { officials }\end{array}$ & $\begin{array}{l}\text { Fred Obe } \\
\text { (president) }\end{array}$ & $\begin{array}{l}\text { Isoko, Delta } \\
1998-2000\end{array}$ \\
\hline 4 & $\begin{array}{l}\text { Movement for the } \\
\text { Survival of Izon } \\
\text { Nationality } \\
\text { (MOSIN) }\end{array}$ & $\begin{array}{l}\text { Clamour for better deal with oil } \\
\text { companies and government. } \\
\text { Pursuesredressof neglect and } \\
\text { underdevelopment }\end{array}$ & $\begin{array}{l}\text { Invasion, overriding; security } \\
\text { and release of their president } \\
\text { from detention at Govt. House, } \\
\text { Yenagoa July } 1998\end{array}$ & $\begin{array}{l}\text { Timi Ogoriba } \\
\text { (president) }\end{array}$ & $1998-2000$ \\
\hline 5 & $\begin{array}{l}\text { Niger Delta Oil } \\
\text { Producing } \\
\text { Communities } \\
\text { (NDOPC) }\end{array}$ & $\begin{array}{c}\text { Agitate against marginalization and } \\
\text { underdevelopment }\end{array}$ & $\begin{array}{c}\text { Violent confrontations; } \\
\text { agreed to conflict resolution } \\
\text { after meeting with Obasanjo } \\
\text { on } 3 \text { Jan. } 1999\end{array}$ & $\begin{array}{l}\text { Saturday Eregbene } \\
\quad \text { (president) }\end{array}$ & $\begin{array}{c}\text { Ijaw } \\
1998-1999\end{array}$ \\
\hline 6 & $\begin{array}{l}\text { Niger Delta Volunteer } \\
\text { Force (NDVF) }\end{array}$ & $\begin{array}{l}\text { Underdevelopment, lack of } \\
\text { benefits from oile xploitation, } \\
\text { and marginalization }\end{array}$ & $\begin{array}{l}\text { Seizures of oil facilities and armed } \\
\text { conflict with the state and Itsekiris. }\end{array}$ & - & $\begin{array}{c}\text { Ijaw } \\
1998-2000\end{array}$ \\
\hline 7 & $\begin{array}{l}\text { Bayelsa Youths } \\
\text { Federation of } \\
\text { Nigeria (BYFN) }\end{array}$ & $\begin{array}{l}\text { Neglect and Underdevelopment; } \\
\text { Youth defense in encounters } \\
\text { with the state }\end{array}$ & $\begin{array}{l}\text { Press statements condemning } \\
\text { state tyranny, militarisation } \\
\text { and human rights abuses }\end{array}$ & $\begin{array}{l}\text { Nengi James } \\
\text { (President) }\end{array}$ & $\begin{array}{c}\text { Ijaw } \\
1999-2000\end{array}$ \\
\hline 8 & $\begin{array}{l}\text { Movement for the } \\
\text { Survival Itsekiri Ethnic } \\
\text { Nationality (MOSIEN) }\end{array}$ & $\begin{array}{l}\text { Seeks federal restructuring } \\
\text { and resource control }\end{array}$ & $\begin{array}{l}\text { News releases, meetings, actions } \\
\text { in the Ijaw-Itsekiri conflict }\end{array}$ & P. Fregene & $\begin{array}{c}\text { Itsekiri, Delta } \\
1998-2000\end{array}$ \\
\hline 9 & $\begin{array}{c}\text { Urhobo Youth } \\
\text { Movement (UYOMO) }\end{array}$ & $\begin{array}{c}\text { Environmental cleaning standards, } \\
\text { growth, jobs and oil production } \\
\text { partnership }\end{array}$ & $\begin{array}{l}\text { Closure of oil production } \\
\text { threats if demands are not } \\
\text { met by Feb } 1999\end{array}$ & $\begin{array}{c}\text { Ejabefio Ogodo } \\
\text { (deputy co-ordinator) }\end{array}$ & $\begin{array}{l}\text { Urhobo Delta } \\
\text { 1999-2000 }\end{array}$ \\
\hline 10 & $\begin{array}{l}\text { Fed. Niger Delta Izon } \\
\text { Communities (FNDIC) }\end{array}$ & $\begin{array}{l}\text { State repression criticism, } \\
\text { call for ownership of capital, jobs, } \\
\text { federal resolutions and growth }\end{array}$ & $\begin{array}{l}\text { Violent meetings between Itsekiris } \\
\text { and the state; oil seizures; threats } \\
\text { against oil workers and foreigners } \\
\text { to leave the region. }\end{array}$ & $\begin{array}{l}\text { Fred Orubebe, } \\
\text { Daniel Ekpebide }\end{array}$ & $\begin{array}{c}\text { Ijaw } \\
1998-2000\end{array}$ \\
\hline
\end{tabular}

Sources: Okafor (1998, 1999), Obari (1998a, 1998b), Fiakpa (1998), Suleiman (1999), Ogoigbe (1998), Ezomon (1999), Amorighoye (2000a), Ezereonwu (2000), Ajayi et al. (1999), Obari et al. (1999), Abugu (1999), Vanguard (1998a, 1998b), Onuorah \& Oliomogbe (1999). 
Table 4. Outline of Pan-ethnic civil society.

\begin{tabular}{|c|c|c|c|c|c|}
\hline $\mathrm{S} / \mathrm{N}$ & Civil Society & Demands/Grievances & Specific Actions & Leadership & Period \\
\hline 1 & $\begin{array}{l}\text { Delta Oil Producing } \\
\text { Communities } \\
\text { Association (DOPCA) }\end{array}$ & $\begin{array}{l}\text { Complaints of negligence, } \\
\text { poverty and pollution issues; } \\
\text { look for competitive advantage }\end{array}$ & $\begin{array}{l}\text { Meetings, interviews, statements } \\
\text { with oil companies }\end{array}$ & $\begin{array}{l}\text { Diamond } \\
\text { Emuobor } \\
\text { (president) }\end{array}$ & 1993-1999 \\
\hline 2 & $\begin{array}{l}\text { Niger Delta Elders } \\
\text { Forum (NDEF) }\end{array}$ & $\begin{array}{l}\text { Low development and unfair } \\
\text { distribution of capital }\end{array}$ & $\begin{array}{l}\text { Advertisements in national } \\
\text { newspapers, } 1999\end{array}$ & E. K. Clark & $1998-2000$ \\
\hline 3 & $\begin{array}{l}\text { Niger Delta Peace } \\
\text { Forum (NDPF) }\end{array}$ & $\begin{array}{l}\text { Disapproval of ecological risks, } \\
\text { negligence and unequal } \\
\text { distribution of resources }\end{array}$ & $\begin{array}{l}\text { News release reproving } \\
\text { armed profession and } \\
\text { support of solutions }\end{array}$ & $\begin{array}{l}\text { Suokere Agidee } \\
\quad \text { (gen. sec) }\end{array}$ & 1999 \\
\hline 4 & $\begin{array}{c}\text { CHICOCO } \\
\text { Movement }(\mathrm{CM})\end{array}$ & $\begin{array}{l}\text { Criticism of hateful laws, } \\
\text { eco-friendly damage and neglect }\end{array}$ & $\begin{array}{l}\text { Meetings, press, calls on the } \\
\text { withdrawal of oil companies }\end{array}$ & $\begin{array}{l}\text { Oronto } \\
\text { Douglas }\end{array}$ & $1997-2000$ \\
\hline 5 & $\begin{array}{l}\text { Students of Oil Mineral } \\
\text { Producing Areas } \\
\text { (SOMPA) }\end{array}$ & $\begin{array}{l}\text { Demands removal of OMPADEC } \\
\text { chairman, (1998), regional graduate } \\
\text { recruitment, release of detained activists }\end{array}$ & $\begin{array}{l}\text { Demonstrations on the major } \\
\text { streets of Port Harcourt in } \\
\text { November } 1998\end{array}$ & - & 1998 \\
\hline 6 & $\begin{array}{l}\text { Movement for the } \\
\text { Survival of Eastern } \\
\text { Nigeria and Niger } \\
\text { Deltans (MOSIENND) }\end{array}$ & $\begin{array}{l}\text { Marginalization and neglect. } \\
\text { Demand that Niger Delta } \\
\text { indigene head OMPADEC }\end{array}$ & $\begin{array}{l}\text { Indicted the federal government } \\
\text { over the appointment of } \\
\text { non-indigene in OMPADEC }\end{array}$ & $\mathrm{E}$ & $\begin{array}{c}\text { Eastern Nigeria } \\
\text { Niger Delta } \\
1998\end{array}$ \\
\hline 7 & $\begin{array}{l}\text { South-South Peoples } \\
\text { Conference (SSOPEC) }\end{array}$ & $\begin{array}{l}\text { Reparation application, equal } \\
\text { profits, federal reform, growth }\end{array}$ & Press & E. K. Clark & $\begin{array}{l}\text { Niger Delta } \\
2000\end{array}$ \\
\hline 8 & $\begin{array}{l}\text { Niger Delta Women } \\
\text { for Justice (NDWJ) }\end{array}$ & $\begin{array}{l}\text { Military deployment and repression } \\
\text { condemnation; negotiation, } \\
\text { federalism \& management of capital }\end{array}$ & $\begin{array}{c}\text { Organized protests in Port } \\
\text { Harcourt against combat-ready } \\
\text { status. }\end{array}$ & $\begin{array}{l}\text { A. Brisibe } \\
\text { (president) }\end{array}$ & $\begin{array}{c}\text { Niger Delta } \\
1999-2000\end{array}$ \\
\hline 9 & $\begin{array}{l}\text { Southern Minorities } \\
\text { Forum (SMF) }\end{array}$ & $\begin{array}{l}\text { Seeks the ownership of wealth, the } \\
\text { derivatives; deplores deprivation, } \\
\text { disparity, federations' negligence } \\
\text { and systemic inequalities }\end{array}$ & $\begin{array}{l}\text { Adverts, responses, support } \\
\text { during the } 1994 \text { constitutional } \\
\text { conference }\end{array}$ & - & 1994-1996 \\
\hline 10 & $\begin{array}{c}\text { Niger Delta } \\
\text { Professionals (NDP) }\end{array}$ & $\begin{array}{l}\text { Deplores politicization and } \\
\text { military brutality, needs and } \\
\text { management of capital }\end{array}$ & $\begin{array}{l}1999 \text { US embassy protest; } \\
\text { the threat to cut oil flow to the } \\
\text { North over sharia inMarch } 2000 . \\
\text { Lawsuit over derivation funds }\end{array}$ & $\begin{array}{l}\text { Godwin O. Im- } \\
\text { ozor }\end{array}$ & $1999-2000$ \\
\hline 11 & $\begin{array}{l}\text { Union of Niger Delta } \\
\text { (UND) }\end{array}$ & $\begin{array}{l}\text { Regulation of capital needs, } \\
\text { abolition of unfavourable } \\
\text { legislation and federal reform }\end{array}$ & $\begin{array}{l}\text { Communications and } \\
\text { conferences }\end{array}$ & $\begin{array}{l}\text { D. O. Dafinone } \\
\text { (chairman) }\end{array}$ & $\begin{array}{l}\text { NigerDelta } \\
2000\end{array}$ \\
\hline 12 & $\begin{array}{l}\text { Traditional Rulers of Oil } \\
\text { Mineral Producing } \\
\text { Communities of Nigeria } \\
\text { (TROPCON) }\end{array}$ & $\begin{array}{l}\text { Support for the theory of } \\
\text { derivation and programmes } \\
\text { for development }\end{array}$ & $\begin{array}{l}\text { Conferences, communications, } \\
\text { press releases, governments } \\
\text { meetings }\end{array}$ & $\begin{array}{l}\text { A. Ukpa } \\
\text { (acting chair- } \\
\text { man) }\end{array}$ & $1995-2000$ \\
\hline 13 & $\begin{array}{c}\text { Bayelsa } \\
\text { Non-Governmental } \\
\text { Organizations Forum } \\
\text { (BANGOF) }\end{array}$ & $\begin{array}{l}\text { Collectively ensure social justice, human } \\
\text { dignity, conflict resolution, good } \\
\text { governance, participatory sustainable } \\
\text { development through interventions, } \\
\text { advocacy and social welfare. }\end{array}$ & $\begin{array}{l}\text { Umbrella body of over } 40 \\
\text { organizations; engage leaders, } \\
\text { the government and its agencies } \\
\text { on issues of accountability and } \\
\text { good governance in Bayelsa State }\end{array}$ & $\begin{array}{l}\text { Godson Jim } \\
\text { Dorgu-Chairman }\end{array}$ & $\begin{array}{l}\text { Yenegoa, } \\
2008\end{array}$ \\
\hline 14 & $\begin{array}{l}\text { Community Partners } \\
\text { for Development } \\
\text { (CPD) }\end{array}$ & $\begin{array}{l}\text { Empower women, youth and children } \\
\text { to achieve a sustainable livelihood; } \\
\text { reconstruct the interface between } \\
\text { human rights and development }\end{array}$ & $\begin{array}{l}\text { Provided economic empowerment } \\
\text { and humanitarian assistance to } \\
\text { both victims and ex-combatants } \\
\text { in Niger Delta }\end{array}$ & 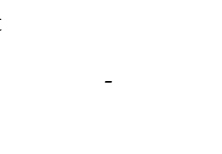 & $\begin{array}{l}\text { Akwa-Ibom, } \\
1997\end{array}$ \\
\hline
\end{tabular}

Sources: Ekeinde (1999), Fagbemi (1999), The Guardian (1999), Ofiebor (1999), Amaize (1999), Akpan (2000), Eze (1999), Ehigiator (2000), Ogbodo (2000), Obari (2000), Onwuemeodo (2000), Nwuke (1998), Amorighoye (2000b). 
Table 5. Outline of environmental and civil human right group in the Niger Delta.

\begin{tabular}{|c|c|c|c|c|c|}
\hline $\mathrm{S} / \mathrm{N}$ & Civil Society & Objectives/Demands & Specific Action & Leadership & Period \\
\hline 1 & $\begin{array}{l}\text { Niger Delta Human } \\
\text { and Environmental } \\
\text { Rescue Organization } \\
\quad(\text { ND-HERO) }\end{array}$ & $\begin{array}{l}\text { Disapproval of military } \\
\text { recruitments, state neglect, } \\
\text { forceful settlement of disputes, } \\
\text { protection of climate and } \\
\text { civil rights. }\end{array}$ & $\begin{array}{l}\text { Detailed monitoring of violence, } \\
\text { abuses of human rights and military } \\
\text { jobs. Interviews, press release and } \\
\text { commentary on the conflict }\end{array}$ & $\begin{array}{l}\text { R. Azibaola } \\
\text { (president) }\end{array}$ & $1998-2000$ \\
\hline 2 & $\begin{array}{c}\text { Ijaw Council For } \\
\text { Human Rights (ICHR) }\end{array}$ & $\begin{array}{l}\text { Resource, ecological and human } \\
\text { right protection of Ijaws }\end{array}$ & $\begin{array}{c}\text { Letters, press communiques } \\
\text { calling for an end to hostilities } \\
\text { and oil companies leaving Ijawland } \\
\text { until conflict issues have } \\
\text { been resolved }\end{array}$ & $\begin{array}{l}\text { Patterson Ogon } \\
\text { (secretary) }\end{array}$ & 1998 \\
\hline 3 & $\begin{array}{l}\text { Environmental Rights } \\
\text { Action (ERA) }\end{array}$ & $\begin{array}{l}\text { Protection of green and } \\
\text { human rights }\end{array}$ & $\begin{array}{c}\text { Press conferences, announcements, } \\
\text { oil leaks and state repression } \\
\text { situation reports }\end{array}$ & $\begin{array}{l}\text { Nimmo Bassey } \\
\text { (president) }\end{array}$ & $1998-2000$ \\
\hline 4 & Oil Watch Group & $\begin{array}{l}\text { Environmental restructuring } \\
\text { and compensation }\end{array}$ & Green reform initiatives & - & 1998 \\
\hline 5 & $\begin{array}{c}\text { Institute of Human } \\
\text { Rights and Humanitarian } \\
\text { Law (IHRHL) }\end{array}$ & - & $\begin{array}{l}\text { Condemnation of military } \\
\text { operation atrocities }\end{array}$ & $\begin{array}{l}\text { Anyakwee } \\
\text { Nsiriovu }\end{array}$ & 1999 \\
\hline 6 & $\begin{array}{l}\text { Niger Delta Wetland } \\
\text { Centre (NDWC) }\end{array}$ & $\begin{array}{l}\text { Research on natural resource } \\
\text { management and human } \\
\text { development activities in } \\
\text { Niger Delta }\end{array}$ & $\begin{array}{l}\text { Partnership with national government } \\
\text { and oil companies towards community } \\
\text { development training, solar energy, } \\
\text { economic empowerment, strengthen } \\
\text { eco-system-based restoration, } \\
\text { sustainable development and } \\
\text { change the practices of the oil } \\
\text { and gas sector }\end{array}$ & & Port-Harcourt \\
\hline 7 & $\begin{array}{l}\text { Social Development } \\
\text { Integrated Centre }\end{array}$ & $\begin{array}{l}\text { Building capacities of individuals } \\
\text { and communities in energy, } \\
\text { environment and climate change, } \\
\text { trade, democracy and social justice; } \\
\text { assist in holding officials and } \\
\text { institutions accountable }\end{array}$ & $\begin{array}{l}\text { Advocated for democracy and } \\
\text { environmental issues }\end{array}$ & $\begin{array}{l}\text { Partnership } \\
\text { with MacArthur } \\
\text { Foundation }\end{array}$ & $\begin{array}{c}\text { Port-Harcourt, } \\
2007\end{array}$ \\
\hline 8 & $\begin{array}{l}\text { Africa Network for } \\
\text { Environment and } \\
\text { Economic Justice } \\
\text { (ANEEJ) }\end{array}$ & $\begin{array}{l}\text { Amplify the voice of the Niger } \\
\text { Delta people; increase their } \\
\text { participation in governance; } \\
\text { contribute towards environmental } \\
\text { rights protection }\end{array}$ & $\begin{array}{l}\text { Provided for economic } \\
\text { empowerment of beneficiaries, } \\
\text { contributed to training of } \\
\text { ex-combatants and provided } \\
\text { them job opportunities }\end{array}$ & David Ugolor & 1997 \\
\hline 9 & $\begin{array}{c}\text { Mangrove Forest } \\
\text { Conservation Society } \\
\text { of Nigeria (MFCSN) }\end{array}$ & $\begin{array}{c}\text { Establishment of conservation } \\
\text { centres, agricultural } \\
\text { programmes }\end{array}$ & $\begin{array}{c}\text { Partnered with Rivers State } \\
\text { government, SPDC, NLNG towards } \\
\text { sustainable co-existence of rural dev. } \\
\text { And mangrove ecosystems across } \\
\text { numerous Niger Delta cities }\end{array}$ & & Rivers, 1995 \\
\hline
\end{tabular}

Source: Offi (1998), Obari (1999), Ekeinde (1999), Obibi (1999), Mordi (1998). 
Table 6. Outline of communal and ethnic civil society.

\begin{tabular}{|c|c|c|c|c|c|}
\hline $\mathrm{S} / \mathrm{N}$ & Civil Society & Objectives/Demands & Action & Leader & Period \\
\hline 1 & $\begin{array}{l}\text { Movement for the } \\
\text { Survival of Ogoni } \\
\text { People (MOSOP) }\end{array}$ & $\begin{array}{l}\text { Protestsecological destruction and } \\
\text { neglect; fight to regulate land, } \\
\text { independence and progress }\end{array}$ & $\begin{array}{l}\text { Peaceful protests against oil } \\
\text { companies and the state which } \\
\text { led to shut down of oil } \\
\text { production since } 1994\end{array}$ & $\begin{array}{l}\text { Ken Saro-Wiwa } \\
\text { 1993-1995 } \\
\text { Ledun Mitee } \\
\text { 1995-2000 }\end{array}$ & $\begin{array}{c}\text { Ogoni, Rivers } \\
\text { 1990-2000 }\end{array}$ \\
\hline 2 & $\begin{array}{l}\text { Ijaw Elders } \\
\text { Forum (IEF) }\end{array}$ & $\begin{array}{l}\text { Militarisation, repression censure; } \\
\text { behest for equity inclusion and } \\
\text { construction programs }\end{array}$ & $\begin{array}{l}\text { Books, reviews, news reports } \\
\text { and statements }\end{array}$ & E. K. Clarke. & $\begin{array}{c}\text { Ijaw } \\
1998-2000\end{array}$ \\
\hline 3 & $\begin{array}{c}\text { Ijaw National } \\
\text { Congress (INC) }\end{array}$ & $\begin{array}{l}\text { Demands for growth and true } \\
\text { federalism: criticism of state } \\
\text { repression }\end{array}$ & $\begin{array}{l}\text { Media, press conference, police } \\
\text { dialogue sessions, Ijaw racial } \\
\text { conflict coordination }\end{array}$ & $\begin{array}{l}\text { Joshua } \\
\text { Fumudoh }\end{array}$ & $\begin{array}{l}\text { Bayelsa, } \\
1991-2000\end{array}$ \\
\hline 4 & $\begin{array}{l}\text { Egbema National } \\
\text { Congress (ENC) }\end{array}$ & $\begin{array}{l}\text { It condemns the petroleum } \\
\text { corporations' moral } \\
\text { irresponsibility. Formed } \\
\text { Egbema Charter }\end{array}$ & $\begin{array}{l}\text { Warns oil companies to take } \\
\text { social responsibility or to } \\
\text { abandon their land }\end{array}$ & $\begin{array}{l}\text { V. Nwango, } \\
\text { J. Duru etc. }\end{array}$ & $\begin{array}{l}\text { Rivers, } \\
1998-2000\end{array}$ \\
\hline 5 & $\begin{array}{l}\text { Isoko Community Oil } \\
\text { Producing Forum } \\
\text { (ICOPF) }\end{array}$ & $\begin{array}{l}\text { Request Shell's facility and } \\
\text { economic development; } \\
\text { opposes renegade } \\
\text { agreements }\end{array}$ & $\begin{array}{l}\text { SHELL gatherings in support } \\
\text { of young people after the } \\
\text { confiscation of oil } \\
\text { companies-1998/99 }\end{array}$ & $\begin{array}{l}\text { Godswill } \\
\text { Edegware } \\
\text { (chairman) }\end{array}$ & $\begin{array}{c}\text { Delta, } \\
1997-2000\end{array}$ \\
\hline 6 & $\begin{array}{l}\text { Bayelsa Indigenes } \\
\text { Association (BIA) }\end{array}$ & $\begin{array}{l}\text { Request allowance, jobs in } \\
\text { oil firms and condemns } \\
\text { military occupation }\end{array}$ & Press statements & $\begin{array}{l}\text { R. J. A. Hobobo } \\
\text { (president) }\end{array}$ & $\begin{array}{l}\text { Bayelsa, } \\
1999-2000\end{array}$ \\
\hline 7 & $\begin{array}{c}\text { Elimotu } \\
\text { Movement (EM) }\end{array}$ & $\begin{array}{l}\text { Abhors the lack of development; } \\
\text { Shell demand to expand } \\
\text { Ogbia and Oloibiri }\end{array}$ & $\begin{array}{l}\text { Closed Shell's Kolo Cree } \\
\text { oil station }\end{array}$ & Maxwell Oko & $\begin{array}{l}\text { Elebele, } \\
1998-2000\end{array}$ \\
\hline 8 & $\begin{array}{l}\text { The Izon National } \\
\text { Development and } \\
\text { Welfare Association } \\
\text { (INADEWA) }\end{array}$ & $\begin{array}{l}\text { deplores environmental and } \\
\text { non-profit damage; calls on oil } \\
\text { companies to have amenities }\end{array}$ & $\begin{array}{l}\text { Press releases; offered the oil } \\
\text { companies the ultimatum of } \\
\text { leaving Ijaw by } 1 \text { Apr. } 1998\end{array}$ & - & $\begin{array}{c}\text { Ijaw } \\
1998-2000\end{array}$ \\
\hline 9 & $\begin{array}{l}\text { Ogoni Solidarity } \\
\text { Forum }\end{array}$ & $\begin{array}{l}\text { Raise awareness over the } \\
\text { harsh conditions of the Niger } \\
\text { Delta and the dilemma of } \\
\text { refugees from the area }\end{array}$ & $\begin{array}{l}\text { Engaged in enlightenment } \\
\text { pro-grammes, economic } \\
\text { empowerment, agricultural } \\
\text { production }\end{array}$ & $\begin{array}{l}\text { Celestine } \\
\text { AkpoBari }\end{array}$ & 2004 \\
\hline 10 & $\begin{array}{c}\text { Conflict Resolution } \\
\text { Trainers Network } \\
\text { (CROTINN) }\end{array}$ & $\begin{array}{l}\text { Build a strong and informed voice } \\
\text { on public policy issues in Nigeria, } \\
\text { peace education, democracy } \\
\text { development, environmental } \\
\text { conflict, re-search and public } \\
\text { enlightenment. }\end{array}$ & $\begin{array}{l}\text { Training on conflict management } \\
\text { and non-violence; conducted and } \\
\text { provided services to individuals in } \\
\text { the reintegration pro-gramme; } \\
\text { facilitated workshops on building } \\
\text { a coalition of local NGOs }\end{array}$ & & $\begin{array}{l}\text { Bayelsa, } \\
1997\end{array}$ \\
\hline
\end{tabular}

Sources: Ukpong (1998), Onuorah \& Oliomogbe (1999), Okafor (1998), Obari (1999). 


\subsection{The Roles CSOs Played in the Reintegration Programme}

Some of the roles and contributions they played towards the reintegration programme in Niger Delta include:

1) Protecting the liberty and freedom of beneficiaries: the CSOs were very active in protecting the rights, privileges and latitude of the recipients, particularly, the ex-combatants in the reintegration programme. They played a role in ensuring that they were not discriminated against either were their rights denied to basic amenities of life or source of livelihood. They had the right to education, religious organizations as well as get employed. They were protected against the hate of the community in ensuring that they were properly secured and not left out in the provision of amenities and jobs. They advocated for their right to free movement as well as basic other things which gave them access like every other civilian to the resources of the country. Orjuela (2005) posits that these protection functions are generally performed by International Non-Governmental Organizations (I-NGOs) that support domestic civil society either indirectly through their presence as monitoring watchdogs or directly through international accompaniment. It aided the success of the reintegration programme as they saw themselves as one being accepted to the system rather than an enemy of the state. The contribution of CSOs towards protection function was limited as the government is charged with the primary responsibility of performing this function.

2) Human Capital Development: the CSOs were active in seeking for jobs and opportunities for these beneficiaries after the reintegration phase. It was required to ensure that they were financially capable, which will enable them to have something to live for and contribute positively to the economy rather than carrying arms. The conflict intensified due to the high-level unemployment, poverty, environmental pollution in the region. The CSOs realized if jobs are not provided for them despite the reintegration programme, they are likely to return to militancy. Thus, they sort to provide jobs and opportunities for them to earn a living, survive and be able to provide and fend for themselves. In such a way, they alleviated poverty from them and gave them a source of life. For some, the CSOs helped to start up their own small business which is additional cash flow to the economy. Also, to achieve this, CSOs became active participants in the micro-credit finance sector through accessing and managing micro credits and supervising funded projects to ensure the growth of the project. Majorly, they were involved in enhancing access to credit facilities, self-employment for the people, development of skills, providing job opportunities and providing support for them. Human capital development is being prioritized in Nigeria to ensure an increase in economic growth.

3) Economic and Social Empowerment: the non-governmental organizations focused on short-term empowerment while the federal government focused on both short- and long-term empowerment of the beneficiaries. By providing job opportunities for the beneficiaries as well as providing funds for them 
to start their small-scale businesses, they, in turn, empowered them economically. Economic empowerment is the capacity of individuals to participate in, contribute to and benefit from growth processes in ways that recognize the value of their contributions, respect their dignity and make it possible to negotiate a fairer distribution of the benefits of growth. They could contribute meaningfully to the GDP of the economy through their source of livelihood and jobs created for them. In some situations, some beneficiaries who were trained overseas got jobs immediately after their training. This is as a result of the influence of government and the CSOs. Social empowerment, on the other hand, is the process of developing a sense of autonomy and self-confidence, acting individually and collectively to change social relationships and the institutions and discourses that excludes the poor people and keep them in poverty. The CSOs were also concerned with developing the self-esteem and confidence of the ex-combatants as it is a means to be self-aware of themselves and their surroundings, thus, building themselves up and engaging in activities that will yield positivity. Primarily, they assisted and implemented small-scale projects to enhance their livelihood, give loans to individuals and groups, and assist in establishing and managing cooperatives amongst themselves.

4) Relief and Humanitarian Assistance: some organizations primary goal was to provide humanitarian assistance to people of the Niger Delta who had lost their homes and families during the conflict. Welfare assistance was delivered to the ex-combatants to get them well settled and prepare them for the reintegration programme and to have no reason to carry arms again before the reintegration programme. They were also at the forefront of the rehabilitation exercise as they are in closer relations to these people than the government. Some of the local organizations partnered with international organizations and also received fund support from various international organizations and corporate bodies to ensure that the victims and ex-combatants are assisted in several ways. Food, toiletries, medicines, clothing and shelter were provided for them in preparation for their reintegration programme and even during the programme itself. The organizations endeavour to cater for the beneficiaries' needs pending the end of the programme and at the end of the programme, keep monitoring their progress and growth to make sure they don't return to the militancy lifestyle.

5) Monitoring the progress of the ex-combatants: as the reintegration programme gets implemented and different beneficiary taken to different places to be trained informally or formally, the growth and development of each ex-combatant are monitored to know the state of mind of the person. Also, the CSOs monitor the actions and progress of the government in honouring their promises towards the reintegration programme. The close monitoring was essential to avoid the outbreak of another conflict and maintain the existing peace. They also monitor the policies such that it does not violate the right and freedom of the ex-combatants. This function is essential. It follows the successes of the 
reintegration programme and at the same time observe the progress of the ex-combatants in dropping the militancy mindset and inculcating the civilian status which will, in turn, shape their life and manner of the way that will eventually add something positive to the country. Through the role of monitoring, the civil society is better able to realize and recognize the needs of the ex-combatants, their fears, successes, failures and their progress to being socialized into the civilian community. They observe how self-aware the ex-combatants are and tender to whatever requirement is needed for them to be effectively transitioned and integrated into the civilian status.

6) Advisory Roles and Socialization: the socialization function was provided by non-governmental organizations, religious organizations, and educational institutions as they have a direct impact on the beneficiaries of the reintegration programme than the government themselves. The organizations help to provide advisory services to these beneficiaries with the issues bothering them and how they can go about doing better with their reintegration and socialization into the civilian society. Pieces of Advice are given at different levels, and their progress is monitored. They serve as mentors who provide advice, suggestions and solutions to the needs of the ex-combatants and play advisory roles to the government on the best and most effective way of managing the reintegration programme. These roles and functions are essential to avoid the relapse of the conflict or the discontent of the people that will further lead to another agitation. The CSOs help the ex-combatants to socialize freely with other people and activities that are going on their surroundings. They initiate citizen-based initiatives, strengthen citizen efficacy and participation in the society so that they can develop their self-confidence and self-esteem and make positive changes both in themselves and to the community. It reconditions their mindset away from the armed world to the civilian status and advises them on how to cope, adjust and maintain a positive relationship with people around.

7) Advocacy Roles: according to (Aall, 2001; Paffenholz, 2003), advocacy is one of the core functions in peacebuilding and primarily a role for domestic civil society. Niger Delta wasn't left out in carrying out this function. The CSOs articulates the interests of the people, their needs, and interests and create communication channels to the government and the general public. They advocated on the rights, needs and freedom of the ex-combatants. It aided in government providing jobs for the people, women inclusion in the reintegration and empowerment programme as well as ensuring the effectiveness in the socialization and integration of the ex-combatants into the civilian society without any discrimination or rebel.

8) Social Service and Welfare: CSOs assisted in providing certain services and provisions that could not be met by the government. They advocate for the provision of basic needs, the affordability of social services and public subsidization of social services for the ex-combatants. Their contribution to the reintegration programme in the aspect of social assistance is such that they engaged in 
various activities as well as partnered with the government to meet the basic needs of the beneficiaries in terms of food, employment, adequate training, and a monthly stipend for food and cash flow. The civil society organizations in partnership with the government provided several training programs for the reintegration programme where they were trained in literacy, numeracy and entrepreneurship which could be used in sustaining their livelihoods and contribute positively to the society. These trainings were not done directly by the actors involved but were contracted to consultants to help in implementing them. In general, they were active in efforts at providing safety nets for the ex-combatants during the reintegration programme. Summarily, they conducted literacy programmes, health awareness and welfare programmes for the challenged, campaigns against human trafficking, immunization campaigns and implementing health projects.

9) Environmental Governance: CSOs raised awareness about the need to protect the environment from progressive degradation, industrial pollution and deforestation. The ecological degradation of the region was the cause of the conflict. Thus, there was a need to protect the environment to prevent it from further damage and the increase in armed groups against the government. The awareness also aided the reintegration programme as the ex-combatants finally felt their voices were being heard, and their needs met. The central objective of this has been sustaining the environment for development, awareness on the issues of the situation, the identification of environmental pollution sites and remediation, and compliance of industrial organizations with environmental policies. It will further reduce the environmental hazard in the region as well as the harm it causes to the people living in that area.

10) Infrastructure Provision: civil society organizations were also responsible for providing infrastructural facilities for the community and region. Many of their homes were destroyed and had become displaced. Thus, some organizations helped in implementing small-scale community infrastructures, providing loans for housing, advocate for infrastructure improvements for the people to ensure a better standard of living for the people and region. One of the basic needs of any individual is shelter, a place to lay their heads on. The civil society organizations -religious organizations, helped in making this available to the beneficiaries during their rehabilitation and reintegration programme, providing social care and needs for them to make them feel accepted and wanted in the society thereby increasing the efficiency of the reintegration programme.

\section{The Challenges of Post-Conflict Reintegration in Niger Delta, Nigeria}

The reintegration programme was faced with lots of challenges which hindered its effectiveness. These are:

1) Corruption and Mismanagement of Funds: this was caused by poor management where there was no proper records and management of the funds 
allocated for the peacebuilding effort in the Niger Delta. Also, there was the politicization of the programme where several ex-generals and officials embezzled and used their "boys" as links to banks to deposit the looted funds into the bank. These short-changed the funds used for peacebuilding as there was not enough cash flow to fund the programme. This challenge was attested to by the Economic and Financial Crimes Commission (EFCC) when they started probing the activities of the PAP and invited the past Special Adviser to President on Niger Delta Affairs over the allegation of diverting of public fund running into millions of Naira. Also, the corruption in the region has long been known to be the main driver and cause of underdevelopment in Niger Delta. Studies have related the culture of fraud to the massive oil wealth and popular discontent in the Delta (Karl, 1997; Smith, 2007; Welch, 1995). The former governor of Bayelsa State, Alamieyeseigha, and James Ibori of Delta State was convicted for the embezzlement of funds, leaving their states dry and penniless (Enweremadu, 2008). Also, money meant for the rehabilitation and training of ex-militants was used by the leaders of the disbanded groups as their offices became pipelines for personal aggrandizement.

2) Inadequate Provision of Resources: the fraudulent and short-changing of funds allocated for the peacebuilding programme affected the provision of infrastructural facilities to the ex-combatants. Many complained about their feeding and non-payment of housing allowance. Their living condition and other facilities led some to some protest. Some ex-combatants were asked to return to their camps until the centre was put in order (Ameh, 2013). This also affected the training of some ex-combatants as it was reported that 13 ex-combatants (Nigeria Amnesty pilots) who were undergoing training at Lufthansa Flight Training School in Germany were sent home for not paying their fees. This situation arose from the inability to pay sundry fees as stipulated in their training manual.

3) The politicization of the programme: the process was heavily politicized, and the absorptive capacities for effective reintegration were highly limited (Azam, Bevan, \& Collier, 1994). Not excluding the Niger Delta reintegration programme, ex-generals and elites of power lobbied the programme which turned it into a political rather than social effort. Some ex-warlords were given extra allowance other than the monthly stipend allocated to them for the price of peace in the region (the binding agreement of 39.5 million dollars between NNPC and the ex-warlords to protect the oil pipelines Ogunde, 2012). This action caused a significant financial disparity between them and their "boys" whom they send to the creek and face constant dangers as they can in anytime revolt against their ex-warlords. Also, with the extra allowance given to them, it could lead to the outrage of other ex-combatants demanding for more which could eventually lead to violence.

4) Government Restriction: the government restricted some local NGOs in partaking in the reintegration process as it was believed they helped propel the 
fuel during the conflict. The restriction reduced the assistance that could be given during reintegration which led to the resurgence of new armed groups under different names causing insecurity, engaging in oil bunkering and posing a threat to the region once again. This situation was what (Gamba, 2003) meant when they said ex-combatants might recreate disbanded armed groups and commence post-war hostilities.

5) Ambiguity in the Conceptualization of Reintegration: there was much ambiguity as to what reintegration entail as the government did not spell out the phases and stages of implementing rehabilitation in the region. Thus, there was no clear-cut objective as to the reason for the reintegration, which led to the over-ranking of economic integration over social and political integration. The prioritization tended to spur up violence such as rape, physical abuse, mutilation, kidnapping, murder, and so on, the return of ex-combatants is capable of triggering anxiety and insecurity in their communities of performance (Knight \& Ozerdam, 2004; Nilson, 2005).

6) Poorly Organized Economic Assistance: economic assistance during reintegration has always been a significant cause for concern due to its poor organization towards the target group, the ex-combatants. The monthly stipend given was not equally distributed. The ex-warlords took over the stipend-payments of their foot soldiers and disbursed funds in a manner that the efforts of ex-militants who surrendered their weapons, signed an agreement with the federal government, and registered for demobilization and reintegration were undermined. Instead of the agreed sixty-five thousand naira that is to be paid, the ex-warlords gave them an amount less than average, and for some people, their names were deleted from the list, adding new names to it to which they never were combatants. After several protests and petitions to the government, then started paying directly to these ex-combatants. Still, the ex-warlords hijacked the whole process as they believed they had the power to disburse, reduce or seize allowances at will. Many a time, fight to break out at the location where the money is disbursed. It is because the amount was slashed into half or into lesser amounts which leads to arguments and disagreements. This situation increases the risk of violence in the region.

7) Delay in Training Programme: there was delay and lapses in the training of ex-militants as some who were rehabilitated were not dispatched for training. At the same time, some were excluded from the training program. The training was based on nepotism of amnesty program officials who favoured and gave unwarranted access to their friends and family. A large proportion of women were neglected and marginalized from the training programs as their obligations to take care of their homes hampered their participation. The marginalized group constitutes the women, children and disabled who are considered weak and require economic, psychological and social assistance (Nilson, 2005). The situation, in turn, means that while some training was delayed, some didn't have means to survive, which poses a permanent threat to the peace of the region. 


\section{Conclusion}

A series of tension and instability characterize the history of the Niger Delta region. The instability is caused by the struggle for resource control and the inability of the Nigerian government to provide a healthy and conducive environment in the region. The 1967-1970 Nigerian civil war is the most noteworthy of these instabilities. Before 2009, very little was done by the federal government to put an end to the conflict that engulfs the region. The 2009 Presidential Amnesty Program birthed the peace process in Niger Delta. PAP took the form of disarmament, demobilization and reintegration. The reintegration phase was the longest phase of them all as it required reorienting and rehabilitating the ex-combatants into civilian status.

The reintegration phase was a process involving the support and contributions of the Nigerian government, local NGOs, some transnational companies and some international organizations. The reintegration programme achieved a level of success in assimilating the ex-combatants by providing formal and informal education, vocational skills and encouraging them to start up their businesses. In contrast, others were provided with jobs at the end of their programme. Despite the level of success attained in the post-conflict reintegration, the programme was faced with lots of challenges which hindered its high effectiveness. The main challenge faced was the inability of the peace actors to reconcile the differences between some of the ex-combatants and the Nigerian government. The failure to reconcile the differences led to the rise in the number of armed groups shortly after the end of the reintegration phase. Presently, there is the resurgence of armed groups in Niger Delta which threatens the peace and security of the country. Therefore, the Nigerian government and CSOs still have a lot of work to do in their contribution towards sustaining peace in the Niger Delta. There is a need for good governance and support from donors. Peace donors should engage more in democratization and aim their support at the grass-root level. There should be a foundation to support better government practices, develop a multi-dimensional strategy and complement their support with funding for innovative local development work.

\section{Conflicts of Interest}

The author declares no conflicts of interest regarding the publication of this paper.

\section{References}

Aall, P. (2001). What Do NGOs Bring to Peacemaking? In C. Crocker, F. Hampson, \& P. Aall (Eds.), Turbulent Peace (pp. 365-383). Washington DC: United States Institute of Peace Press.

Aaron, K. K., \& George, D. (2010). Placebo as Medicine: The Poverty of Development Intervention and Conflict Resolution Strategies in the Niger Delta Region of Nigeria. Port Harcourt: Kemuela Publications.

Abazie-Humphrey, M. (2014). Engaging the Nigerian Niger Delta Ex-Agitators: The Im- 
pacts of the Presidential Amnesty Program on Economic Development. In Paper Delivered at 14th EADI (European Association of Development Institutes) General Conference on "Responsible Development in a Polycentric World: Inequality, Citizenship, and Middle Classes". Abuja: Office of the Special Adviser to the Nigeria President on Niger Delta.

https://www.eadi.org/typo3/fileadmin/Documents/Events/General_Conference/2014/g c2014-abazie-humphrey-41.pdf

Abugu, U. (1999). MOSIEN Asks FG to Hand Off Oil Matters. Vanguard, 23 Nov.

Ajayi, R., Ikwunze, C., \& Ogoigbe, E. (1999). Urhobo Youths Issue Ultimatum to Oil Firms. Vanguard, 14 Jan.

Akpan, A. B. (2000). Group Threatens to Cut Oil Supplies to the North. The Guardian, 6 Mar.

Alusala, N. (2011). Reintegrating Ex-Combatants in the Great Lakes Region. Pretoria: Institute for Security Studies.

Amaize, E. (1999). Ijaws Agree to Ceasefire (pp. 1-2). Vanguard, 4 Jan.

Ameh, C. G. (2013). Amnesty: Fear Grips Presidency as Niger Delta Militants Plan to Invade Abuja. Daily Post, 8 Oct.

Amorighoye, N. (2000a). Isoko Want Headship of Development Commission. Vanguard, 21 Feb.

Amorighoye, N. (2000b). Oil Producing States Make a Case for 25\% Revenue Formula. Vanguard, 29 Mar.

Anderson, R. (2015). Intervention at Risk: The Vicious Cycle of Distance and Danger in Mali and Afghanistan. Journal of Intervention and Statebuilding, 9, 519-541. https://doi.org/10.1080/17502977.2015.1054655

Azam, J., Bevan, D., \& Collier, P. (1994). Some Economic Consequences of the Transition from the Civil War to Peace. Washington DC: World Bank Policy Research.

Barnett, M., Kim, H., O’Donnell, M., \& Sitea, L. (2007). Peacebuilding: What Is in a Name? Global Governance, 13, 35-58. https://doi.org/10.1163/19426720-01301004

Bloomfield, D., \& Reilly, B. (1998). The Changing Nature of Conflict and Conflict Management. Stockholm: Institute for Democracy and Electoral Assistance (IDEA).

Boutros-Ghali, B. (1992). An Agenda for Peace. New York: United Nations. https://doi.org/10.1177/004711789201100302

Boutros-Ghali, B. (1996). An Agenda for Democratization. United Nations, New York.

Bratton, M. (1992). Civil Society and Political Transitions in Africa. In J. W. Harbeson et al. (Eds.), Civil Society and the State in Africa (Vol. 11, No. 6, pp. 33-50). Boston: Institute for Development Research (IDR) Report.

CIVICUS (2011). Civil Society Index for Guinea. Guinean Civil Society: Between Activity and Impact. Johannesburg: World Alliance for Citizen Participation.

Daniel, S. (2014). Amnesty Programme: Schneider Employs 15 Niger Delta Trainees. Vanguard News, 14 Jun.

https://www.vanguardngr.com/2014/06/amnesty-prog-schneider-employs-15-niger-del ta-trainees/

Deutsch, M., \& Coleman, P. T. (2000). The Handbook of Conflict Resolution: Theory and Practice. San Francisco, CA: Jossey-Bass.

Dunn, E. (1996). Money, Morality and Modes of Civil Society among American Mormons. In C. Hann, \& E. Dunn (Eds.), Civil Society: Challenging Western Models (pp. 1-6). London: Routledge. 
Ebeku, K. S. A. (2001). Oil and the Niger Delta People: The Injustice of the Land Use Act. VRÜVerfassung und Recht in Übersee, Nomos e-library, 35, 201-231.

https://doi.org/10.5771/0506-7286-2002-2-201

Ehigiator, K. (2000). Niger Delta Union Wants 100\% Resource Control, Insists on Sovereign Confab. Vanguard.

Ekeinde, A. (1999). Operation Kill and Rape (pp. 30-31). Tell, 8 Feb.

Elowyn, C. (2011). Ogoni People Struggle with Shell Oil, Nigeria, 1990-1995. Swarthmore, PA: Global Nonviolent Action Database, Swarthmore College.

Enweremadu, D. (2008). The Vicious Circle: Oil, Corruption, and Armed Conflicts in the Niger Delta. In International Conference on the Nigerian State, Oil Industry and Niger Delta (p. 449). Port Harcourt: Harvey.

Eze, I. (1999). Niger Delta Professionals Decry Occupation of Odi. Vanguard, 1 Dec.

Ezereonwu, J. (2000). Groups Grant Shell Provisional Return to Oil Rigs. The Guardian, 17 May.

Ezomon, E. (1999). In Niger Delta, the Wound Runs Deep (p. 15). The Guardian, 29 Jan.

Fagbemi, A. (1999). Douglas Outlines How to Pacify Ijaw Youths (p. 48). The Guardian, 13 Jan.

Fiakpa, L. (1998). Ijaws Gun for Secession (p. 20). Tell, 26 Oct.

Fischer, M. (2004). Recovering from Violent Conflict: Regeneration and Reintegration as Elements of Peacebuilding. Berlin: Berghof Research Center for Constructive Conflict Management, Berghof Handbook on Conflict Transformation.

https://doi.org/10.1007/978-3-663-05642-3_18

Folami, D. (2014). Federal Government to Spend N35.83bn EX-Militants This Year. https://www.vanguardngr.com/2014/02/fg-spend-n35-83bn-ex-militants-2014/

Fukuyama, F. (1995). The Primacy of Culture. Journal of Democracy, 6, 7-14. https://doi.org/10.1353/jod.1995.0007

Galtung, J. (1976). Three Approaches to Peace: Peacekeeping, Peacemaking and Peacebuilding. In Peace, War and Defense: Essays in Peace Research II (pp. 292-304). Copenhagen: Christian Elders.

Gamba, V. (2003). Managing Violence: Disarmament and Demobilization. In J. Darby, \& R. MacGinty (Eds.), Contemporary Peacemaking, Conflict, Violence and Peace Processes (pp. 125-136). Basingstoke: Palgrave Macmillan.

Grindle, M. S. (1996). Challenging the State: Crisis and Innovation in Latin America and Africa. Cambridge: Cambridge University Press.

https://doi.org/10.1017/CBO9780511521829

Hamre, J. J., \& Sullivan, G. R. (2002). Towards Post-Conflict Reconstruction. The Washington Quarterly, 25, 85-96. https://doi.org/10.1162/016366002760252554

Harbeson, J. W., Rothchild, D., \& Chazan, N. (1992). Civil Society and the State in Africa. Boulder, CO: Lynne Rienner.

Human Rights Watch, HRW (1999). The Price of Oil: Corporate Responsibility and Human Rights Violations in Nigeria's Oil Producing Communities.

Ibude, S. E. (2011). An Evaluation of the Presidential Amnesty Programme for the Niger Delta Militants in Nigeria; Implications for Peace and Hydro-Carbon Production in the Oil-Rich Region. A Research Proposal Presented to the Department of Political Science and Public Administration, Benin City: University of Benin.

Ikelegbe, A. (2010). Oil, Resource Conflict and the Post Conflict Transition in the Niger Delta Region: Beyond the Amnesty. CPED Monograph Series No. 3. 
Ikelegbe, A. O. (1999). State, Ethnic Youth Associations and Conflict: An Analysis of the Associational Encounters with the State in the Niger Delta Region in Insurgent Civil Society in Nigeria. Kano: Centre for Research and Documentation.

Ikelegbe, A. O. (2001). The Perverse Manifestation of Civil Society: Evidence from Nigeria. Journal of Modern African Studies, 39, 1-24. https://doi.org/10.1017/S0022278X0100355X

Ikelegbe, A., \& Umukoro, N. (2014). The Amnesty Programme and the Resolution of the Niger Delta Crisis: Progress, Challenges and Prognosis. CPED Monograph Series No. 14.

Ikelegbe, O. A. O. (2013). The State and Civil Society in Nigeria: Towards a Partnership for Sustainable Development. Centre for Population and Environmental Development (CPED), CPED Monograph Series No. 7, Benin City: Ambik Press Ltd.

International Crisis Group (2006). The Swamps of Insurgency: Nigeria's Delta Unrest. Africa Report 115, Benin City: International Crisis Group.

https://www.crisisgroup.org/africa/west-africa/nigeria/swamps-insurgency-nigerias-del ta-unrest

Karl, T. L. (1997). The Paradox of Plenty: Oil Booms and Petro-States. Berkeley, CA: University of California Press. https://doi.org/10.1525/9780520918696

Keane, J. (1988). Introduction. In J. Keane (Ed.), Civil Society and the State: New European Perspectives (pp. 1-31). London: Verso.

Kingma, K. (2001). Demobilizing a Reintegrating Soldiers: Lessons from Africa. In L. Reychler, \& T. Paffenholz (Eds.), Peacebuilding: A Field Guide (pp. 405-415). London: LienneRienner Publishers.

Kligman, G. (1990). Reclaiming the Public: A Reflection on Recreating Civil Society in Romania. Eastern European Politics and Societies, 4, 393-438. https://doi.org/10.1177/0888325490004003002

Knight, M., \& Ozerdam, A. (2004). Guns, Camps and Cash: Disarmament, Demobilization, and Reinsertion of Former Combatants in Transitions from War to Peace. Journal of Peace Research, 41, 499-516. https://doi.org/10.1177/0022343304044479

Lederach, J. P. (2003). The Little Book of Conflict Transformation. Intercourse, PA: Good Books.

Makumbe, J. (1998). Is There a Civil Society in Africa? International Affairs, 74, 305-317. https://doi.org/10.1111/1468-2346.00018

Miall, H. (2004). Conflict Transformation: A Multi-Dimensional Task. Berlin: Berghof Research Center for Constructive Conflict Management.

https://doi.org/10.1007/978-3-663-05642-3_4

Mordi, P. (1998). Ijaw Group Tells Oil Firms to Cease Operations, Withdraw (p. 5). The Guardian, 24 Dec.

Nilson, A. (2005). Reintegrating EX-Combatants in Post-Conflict Societies. Stockholm: Swedish International Development Agency.

Nwuke, O. (1998). OMPADEC: Opposition to Bukar Alli's Appointment Swells (pp. 1-2). Independent Monitor, 5-8 November.

Obari, J. O. (1998a). Oil Workers, Military Get Ultimatum to Leave Ijaw Area (p. 56). The Guardian, 16 Dec.

Obari, J. O. (1998b). Egbesu Boys: Ijaws Parallel Army (pp. 17, 19). The Guardian, 6 Dec.

Obari, J. O. (1999). Group Warns Oil Firms over Alleged Neglect. The Guardian, 13 Aug.

Obari, J. O. (2000). South-South Urges Legal Action over Revenue Allocation. The 
Guardian, 16 Mar.

Obari, J. O., Okafor, C., \& Shokumbi, L. (1999). Amid Fresh Troubles, Ijaw Leaders Criticize Attack. The Guardian, 8 Jan.

Obi, C. (2009). Nigeria's Niger Delta: Understanding the Complex Drivers of Violent Oil-Related Conflict. Africa Development, 34, 103-128. https://doi.org/10.4314/ad.v34i2.57373

Obibi, C. (1999). Ijaw Women Protest Troops Deployment to Bayelsa. The Guardian, 12 Jan.

Offi, S. (1998). Abubakar Was Misguided (p. 13). Tell, 2 Nov.

Office of the Special Adviser to the President on Niger Delta, OSAPND (2014). Strides of the Presidential Amnesty Programme. Abuja.

Ofiebor, O. (1999). There Will Be Anarchy-Interview of Rev. Diamond Emuobor (pp. 28-29). The News, 18 Jan.

Ogbodo, J. A. (2000). Youths Reject Funding Formula for NDDC. Vanguard, 6 Mar.

Ogoigbe, E. (1998). Isoko Youths Seize Oil Flow Stations. Vanguard, 18 Dec.

Ogunde, A. (2012). NNPC Awards Niger Delta Militants Billions in Security Contracts. Business News, 23 Aug.

Okafor, C. (1998). Youths Shut Five Shell Flow Stations (pp. 1, 4). The Guardian, 18 Dec.

Okafor, C. (1999). Group Advises Oil Firms to Withdraw Workers. The Guardian, 23 Nov.

Olokor, F. (2016). FG to Stop Amnesty Programme in 2018. Punch News, 24 Feb.

Oluwaniyi, O. (2011a). Post-Amnesty Programme in the Niger Delta: Challenges and Prospects. Conflict Trends, 4, 46-54.

Oluwaniyi, O. (2011b). The DDR Process in Post-Conflict Peacebuilding Process: Evaluating Post-Amnesty Challenges in Nigeria's Niger Delta Region. Unpublished Manuscript.

Onuorah, M., \& Oliomogbe, H. (1999). Groups Seek Troops Withdrawal from Bayelsa (p. 40). The Guardian, 18 Jan.

Onwuemeodo, S. (2000). We'll Not Give Up This Fight. Vanguard, 17 Jan.

Orjuela, C. (2005). Civil Society in Civil War, Peace Work and Identity Politics in Sri Lanka. PhD Dissertation, Göteborg: Department of Peace and Development Research, University Göteborg.

Osah, G., \& Alao, D. (2014). Evaluation of Potentials for Peace Sustainability in the Post Amnesty Niger Delta, Nigeria. IOSR Journal of Humanities and Social Science, 19, 8-16. https://doi.org/10.9790/0837-191030816

Paffenholz, T. (2003). Community-Based Bottom-Up Peacebuilding. The Development of the Life and Peace Institute's Approach to Peacebuilding and Lessons Learned from the Somalia Experience (1990-2000). Uppsala: Life and Peace Institute.

Paffenholz, T. (2009). Civil Society and Peacebuilding. GSDRC Applied Knowledge Services. https://gsdrc.org/document-library/civil-society-and-peacebuilding

Rotberg, R. I. (1996). Vigilance and Vengeance: NGOs Preventing Ethnic Conflict in Divided Societies. Washington DC: Brookings Institution.

Schmitter, P. (1995). On Civil Society and Consolidation of Democracy: Ten Propositions. Mimeograph, Stanford, CA: Stanford Department of Political Science.

Smith, D. J. (2007). A Culture of Corruption: Everyday Deception and Popular Discontent in Nigeria. Princeton, NJ: Princeton University Press. 
Suleiman, T. (1999). Drumbeats of War. The News, 18 Jan.

Technical Committee on the Niger Delta (2008). Report of the Technical Committee on the Niger Delta.

http://www.waado.org/NigerDelta/niger_delta_technical_com/NigerDeltaTechnicalRe port.pdf

Tester, K. (1992). Civil Society. New York: Routledge.

The Brahimi Report (2000). The Report of the Panel on United Nations Peace Operations. Geneva: United Nations General Assembly.

The Guardian (1999). Groups Allege Deployment of Soldiers to Niger Delta. The Guardian, 16 Nov.

Udegbuman, K. C. W. (2013). Repositioning Nigeria's Amnesty Programme for Conflict Transformation and Post-Conflict Peacebuilding in the Niger Delta Region of Nigeria. Singaporean Journal of Business Economic, and Management Studies, 2, 42-58. https://doi.org/10.12816/0003840

Ukpong (1998). Ijaws Adamant as Mobil Repairs Pipes. Vanguard, 23 Feb.

UN DPKO, United Nations Department of Peacekeeping Operations (2010). Second Generation Disarmament, Demobilization and Reintegration (DDR) Practices in Peace Operations. New York: UN Department of Peacekeeping Operations.

United Nations (1994). An Agenda for Development: Report of the Secretary-General. UN Doc A/48/935.6 May.

United Nations (2006). What Is DDR? United Nations Disarmament, Demobilization and Reintegration Resource Center.

United Nations Development Program, UNDP (1994). Human Development Report. New York: Oxford University Press. https://doi.org/10.18356/87e94501-en

United Nations, UN (2010). Second Generation Disarmament, Demobilization and Reintegration (DDR) Practices in Peace Operations. New York: Department of Peacekeeping Operations.

Usman, S. (2008). Why Nigeria Remains Poor Despite Being Rich (pp. 32-35). Tell Magazine, 18 Feb.

Uzodinma, E. (2013). Amnesty: Task Force Hands over 39,880 Assorted Arms and Ammunition to Nigeria Army. The Daily Post, 16 March.

http://www.dailypost.ng/2013/03/16/amnesty-task-force-hands-over-39880-assorted-ar ms-and-ammunition-to-nigerianarmy

Vanguard (1998a). Angry Youths Storm Govt. House, Free Leader. Vanguard, 23 Jul.

Vanguard (1998b). Oil Communities Sue FG over OMPADEC Boss (p. 3). Vanguard, 3 Nov.

Vanguard News (2014). From Creek Warlords to Experts in Oil \& Gas: The Story of Ex-Niger Delta Militants. Vanguard News.

https://www.vanguardngr.com/2014/12/creek-warlords-experts-oil-gas-story-ex-nigerdelta-militants/

Watt, W. J. (2010). Insurgency and the Prospect for Development and Democracy in the Niger Delta.

Welch, C. E. (1995). The Ogoni and Self-Determination: Increasing Violence in Nigeria. Journal of Modern African Studies, 33, 636.

https://doi.org/10.1017/S0022278X00021479 